\section{Plans resurrected to raise Venice above the encroaching sea}

\section{Alison Abbott, Munich}

Venice could be saved from sinking into the sea by using oil-industry technology to pump fluid underneath the city, says a team of geomechanical engineers.

Led by Giuseppe Gambolati of the University of Padua, the group published its proposal in a paper last month (A. Comerlati et al. Eos 84, 546, 552-553; 2003). The idea revisits a proposal first mooted in the 1970s, but Gambolati's team claims that advances in technology would now allow Venice to be raised safely.

The proposal will next be considered

by CORILA, the consortium charged with coordinating research into the city's lagoon system.

Venice floods regularly, owing to climate-induced increases in sea levels in the lagoon and to over-extraction of groundwater, which has led to subsidence.

The Consorzio Venezia Nuova, the public authority responsible for protecting Venice, has taken various steps. These include raising the pavement in very lowlying areas, and building a controversial, huge mobile flood barrier called MOSE, whose gates will close during extreme sea surges (see Nature 424, 608-609; 2003). MOSE, costed at $€ 3$ billion (US\$3.8 billion), is due to come into operation in 2011 - but rising sea levels could render it ineffective well within 100 years.

Gambolati says that his plan could lift Venice by up to $30 \mathrm{~cm}$ in 10 years, "which would help to counter the effect of rising sea levels and extend MOSE's useful life".

His proposal involves injecting either carbon dioxide from local power stations or - more simply and cheaply - sea water, into a sandy layer 600-800 metres below the lagoon. The layer is sandwiched between clay below and 25 metres of relatively impermeable cap rock above.

Pierpaolo Campostrini, director of CORILA, says of the earlier proposals to pump fluid below Venice: "The ideas then involved pumping only 40 or 50 metres below the surface, which would have led to uneven raising."

Gambolati says that slow pumping over a period of 10 years at greater depth should allow lifting to be even. Sceptics, such as Rafael Bras, a hydrologist from the Massachusetts Institute of Technology, warn that much more information is needed to establish the idea's feasibility.

CORILA now plans a feasibility study, including geological and geophysical analyses of the sea bed in the lagoon and a test drilling site a safe distance away.

\title{
Intelligence law draws fire over NSF security project
}

Geoff Brumfiel, Washington

The US Congress has told the National Science Foundation (NSF) to coordinate research on intelligence matters. But critics say that if the research agency acts as instructed, it will violate its tradition of openly disseminated science.

The Intelligence Authorization Act for 2004, signed into law on 13 December, calls for the NSF to hold two workshops to coordinate research in the behavioural, psychological and physiological sciences for the purpose of government security evaluations. NSF officials are also required to head a committee of experts in defence, law enforcement and intelligence advising the government on research into security screening procedures, such as lie-detector tests.

The act specifies that the workshops and panel are exempt from government "sunshine laws", which would open the meetings and documents to public examination.

"This is at odds with an NSF-declared commitment to openness," protests Steven Aftergood, who directs the Project on Government Secrecy at the Federation of American Scientists in Washington. Such exemptions are increasingly routine in new legislation related to security, he says.

The NSF and the White House Office of Science and Technology Policy would receive US $\$ 500,000$ from the director of the Central Intelligence Agency to carry out the workshops and committee work. Because the final budget for intelligence is classified, officials were unable to say whether this expenditure is going ahead.

The NSF already works in areas related to

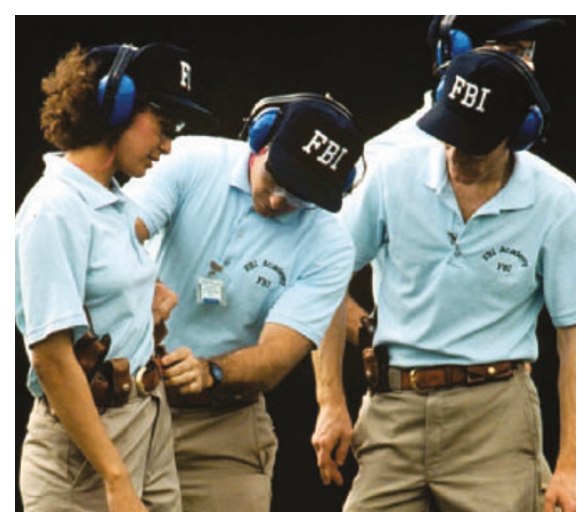

Close encounter: FBI trainees expect to work in secrecy, but scientists are taking a different view.

homeland security. Its Approaches to Combat Terrorism initiative, for example, has spent roughly US $\$ 3.5$ million on research for the intelligence community. But all this work is openly published.

The Senate intelligence committee is said to have inserted language mandating the workshops following a study by the National Academy of Sciences last year. The study had called for a research programme on security screening that would "operate under the normal rules of scientific freedom and openness to the extent possible while protecting national security". A committee spokesman was not available for comment.

NSF officials say the programme will not violate the agency's commitment to openness. "No one at the NSF imagines that this is calling for some kind of closed or classified workshop," says Curt Suplee, who directs the NSF office of legislative and public affairs.

\section{Europe warned against research council}

\section{Jim Giles, London}

The Royal Society has poured cold water on plans to create a central funding body for science in Europe.

In a working paper due to be released on 15 January, the influential society warns that the proposed European Research Council (ERC) might become excessively bureaucratic and prone to political influence. It also charges that the ERC's funding could ultimately come at the expense of existing, national research agencies, and that the body is unlikely to help raise Europe's research spending to US levels.

Last October, a report from science-policy experts recommended creating the ERC within three years, with an annual budget of $€ 2$ billion (US $\$ 2.6$ billion). The report said the council should be politically answerable to both the European Parliament and European Union (EU) member states, although its distribution of grants would be based purely on scientific merit (see Nature 425, 440;2003).

But the Royal Society says the EU Council of Ministers, which is now considering the report, should think hard before legislating for an ERC. Julia Higgins, a chemist at Imperial College London, and a vice-president of the society, says that despite ERC supporters' talk of "new money" for the council, funds will all come from member states in the end.

"If the EU raises money from member states, that could ultimately affect their own research budgets," says Higgins. 